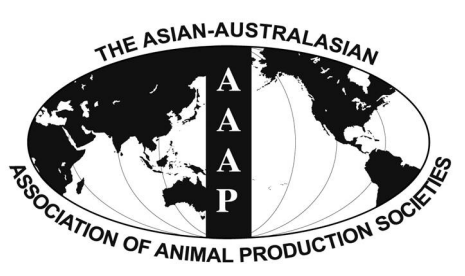

Open Access

Asian Australas. J. Anim. Sci.

Vol. 28, No. 12 : 1742-1750 December 2015

http://dx.doi.org/10.5713/ajas.14.0131

www.ajas.info

pISSN 1011-2367 elSSN 1976-5517

\title{
Branched-chain Amino Acids are Beneficial to Maintain Growth Performance and Intestinal Immune-related Function in Weaned Piglets Fed Protein Restricted Diet
}

\author{
M. Ren ${ }^{1,2}$, S. H. Zhang ${ }^{1}$, X. F. Zeng ${ }^{1}$, H. Liu ${ }^{1}$, and S. Y. Qiao ${ }^{1, *}$ \\ ${ }^{1}$ State Key Laboratory of Animal Nutrition, China Agricultural University, Beijing 100193, China
}

\begin{abstract}
As a novel approach for disease control and prevention, nutritional modulation of the intestinal health has been proved. However, It is still unknown whether branched-chain amino acid (BCAA) is needed to maintain intestinal immune-related function. The objective of this study was to determine whether BCAA supplementation in protein restricted diet affects growth performance, intestinal barrier function and modulates post-weaning gut disorders. One hundred and eight weaned piglets $(7.96 \pm 0.26 \mathrm{~kg})$ were randomly fed one of the three diets including a control diet ( $21 \%$ crude protein $[\mathrm{CP}], \mathrm{CON})$, a protein restricted diet (17\% CP, PR) and a BCAA diet (BCAA supplementation in the PR diet) for $14 \mathrm{~d}$. The growth performance, plasma amino acid concentrations, small intestinal morphology and intestinal immunoglobulins were tested. First, average daily gain (ADG) $(\mathrm{p}<0.05)$ and average daily feed intake (ADFI) $(p<0.05)$ of weaned pigs in PR group were lower, while gain:feed ratio was lower than the CON group $(p<0.05)$. Compared with PR group, BCAA group improved ADG $(\mathrm{p}<0.05)$, ADFI $(\mathrm{p}<0.05)$ and feed:gain ratio $(\mathrm{p}<0.05)$ of piglets. The growth performance data between $C O N$ and BCAA groups was not different $(p>0.05)$. The PR and BCAA treatments had a higher $(p<0.05)$ plasma concentration of methionine and threonine than the CON treatment. The level of some essential and functional amino acids (such as arginine, phenylalanine, histidine, glutamine etc.) in plasma of the PR group was lower $(\mathrm{p}<0.05)$ than that of the CON group. Compared with CON group, BCAA supplementation significantly increased BCAA concentrations $(\mathrm{p}<0.01)$ and decreased urea concentration $(\mathrm{p}<0.01)$ in pig plasma indicating that the efficiency of dietary nitrogen utilization was increased. Compared with CON group, the small intestine of piglets fed PR diet showed villous atrophy, increasing of intra-epithelial lymphocytes (IELs) number $(p<0.05)$ and declining of the immunoglobulin concentration, including jejunal immunoglobulin A $(\operatorname{IgA})(\mathrm{p}=0.04)$, secreted $\operatorname{IgA}(\operatorname{sgA})(\mathrm{p}=0.03)$ and immunoglobulin $\mathrm{M}(\mathrm{p}=0.08)$, and ileal IgA $(\mathrm{p}=0.01)$ and immunoglobulin $\mathrm{G}(\mathrm{p}=0.08)$. The BCAA supplementation increased villous height in the duodenum $(\mathrm{p}<0.01)$, reversed the trend of an increasing IELs number. Notably, BCAA supplementation increased levels of jejunal and ileal immunoglobulin mentioned above. In conclusion, BCAA supplementation to protein restricted diet improved intestinal immune defense function by protecting villous morphology and by increasing levels of intestinal immunoglobulins in weaned piglets. Our finding has the important implication that BCAA may be used to reduce the negative effects of a protein restricted diet on growth performance and intestinal immunity in weaned piglets. (Key Words: Weaned Pig, Growth Performance, Immunity, Small Intestine, Morphology, Immunoglobulin)
\end{abstract}

\section{INTRODUCTION}

As a component of innate immune system, the intestinal barrier is the first defense line against noxious pathogens

\footnotetext{
* Corresponding Author: S. Y. Qiao. Tel: +86-10-62731456, Fax: +86-10-62733688, E-mail: qiaoshy@mafic.ac.cn

2 Animal Science College, Anhui Science and Technology University, Anhui 233100, China.

Submitted Feb. 21, 2014; Revised Apr. 30, 2014; Accepted Jun. 24, 2014
}

and antigens during weaning stress and it directly affects body health (Wells et al., 2010). The intestinal barrier composes of a thick secreted mucus layer, a layer of epithelial cells and the underlying non-epithelial mucosal cells, mainly leukocytes (McGuckin et al., 2009). Meanwhile, immunoglobulins, host defense peptides and cytokines are produced by intestinal cells to participate the intestinal mucosal immune system (Pié et al., 2004; Nofrarías et al., 2006; Pomorska-Mól and Markowska- 
Daniel, 2011). Intestinal mucosal integrity (assessed by intestinal morphology) and immunoglobulins are commonly used to evaluate function of the intestinal immunity (Mao et al., 2011). In weaned piglets, the intestinal immune system is easily disturbed because of immature immunity and enteric antigenic challenges (McCracken et al., 1995) which trigger mucosal and systemic inflammatory responses (Wang et al., 2008; Smith et al., 2010). Thus diarrhea, growth stasis and post-weaning multi-systemic wasting syndrome commonly occur immediately after weaning (Wang et al., 2008). The economic impact of those diseases is huge because of the considerable losses due to mortality or production of non-marketable pigs (Rose, 2003).

During the repairing period after weaning, the most important thing is to decrease the stress and the irritation of antigens from feed and to strengthen the intestinal innate immunity, and the main strategies to improve the intestinal immune-related function are the production of secretory immunoglobulin A (sIgA) (Santaolalla et al., 2011). Supplementing free amino acids (FAA) in low crude protein (CP) diet, as one nutritional strategy (Lallès et al., 2007), have been demonstrated to keep post-weaning gut disorder under control (Htoo et al., 2007; Yue and Qiao, 2007; Heo et al., 2008). For decades, dietary supplementation with amino acids (AA) has been proposed in various physiological or pathological conditions. There has been great interest in the effects of AA on intestinal immunerelated function. Several studies were focused on the effects of glutamine (Calder and Yaqoob, 1999; Carr et al., 2010), arginine (Evoy et al., 1998; Tan et al., 2009; Yoneda et al., 2009) and threonine (Mao et al., 2011) as the fuel and protein (such as mucin) synthesis function, where little is known about the impact of branched-chain amino acids (BCAAs) on the intestinal innate immunity. Cell culture and animal feeding trials indicated that the deficiency of BCAA affected the efficiency of immune function because of the inability of protein synthesis (Con et al., 2011; Powell et al., 2012; Simone et al., 2013). Therefore, the objective of the current study is to determine whether BCAA supplementation in a protein restricted diet improves the intestinal immune barrier function and intestinal health in weaning piglets.

\section{MATERIAL AND METHODS}

\section{Animals}

The experiment was conducted at the experimental farm of China Agricultural University, with the protocol for animal use approved by the Animal Care and Use Committee of China Agricultural University. A total of 108 crossbred (Landrace $\times$ Yorkshire $\times$ Duroc) piglets $(7.96 \pm 0.26$ $\mathrm{kg}$ ) weaned at $28 \pm 1 \mathrm{~d}$ of age were grouped on the basis of body weight $(\mathrm{BW})$ and sex and then allocated to 18 pens for feeding three different diets, with 6 pigs in each pen (all barrow or all gilt) $\left(1.8 \times 2.1 \mathrm{~m}^{2}\right)$. All piglets had ad libitum access to feed and water throughout the $14 \mathrm{~d}$ experimental period. The average temperature in the stable during the experiment was $26^{\circ} \mathrm{C}$.

\section{Experimental design}

The experiment was conducted as a randomized complete block design and the sex was considered as random effect. The single-factor arrangement was designed with three dietary treatments. The control treatment (CON) was the base corn-soybean meal diet and had the general protein level $(21 \% \mathrm{CP})$. The protein restricted treatment (PR) had lower content of protein $(17 \% \mathrm{CP})$ and four essential AA (lysine, methionine, threonine and tryptophan) were supplemented in it to the National Research Council (NRC) requirements (NRC, 1998). The BCAA diet was supplementation with BCAAs in PR diet according the NRC requirement (NRC, 1998). All pigs were weighed at the beginning and end of the experiment. Feed added to the feeder and any wasted feed were weighed. These data was used to calculate average daily gain (ADG), average daily feed intake (ADFI), and gain:feed ratio (G:F).

\section{Chemical analysis}

The ingredient composition and chemical analysis of the

Table 1. Composition of experimental diets ( $\%$ as-fed basis)

\begin{tabular}{lccc}
\hline Ingredients & $\mathrm{CON}^{2}$ & $\mathrm{PR}$ & $\mathrm{BCAA}$ \\
\hline Corn $(8.7 \% \mathrm{CP})$ & 55.14 & 65.71 & 64.90 \\
Dehulled soybean meal $(47.9 \% \mathrm{CP})$ & 19.70 & 8.00 & 8.00 \\
Soy protein concentrate $(65 \%)$ & 5.00 & 5.00 & 5.00 \\
Fish meal $(64.5 \% \mathrm{CP})$ & 4.00 & 4.00 & 4.00 \\
Whey powder $(3 \% \mathrm{CP})$ & 10.00 & 10.00 & 10.00 \\
Soybean oil & 2.10 & 2.30 & 2.60 \\
Salt & 0.34 & 0.35 & 0.35 \\
Limestone & 0.55 & 0.43 & 0.43 \\
Dicalcium phosphate, $\mathrm{CaHPO}_{4}$ & 1.30 & 1.50 & 1.50 \\
Zinc oxide, ZnO & 0.30 & 0.30 & 0.30 \\
Vitamin-mineral premix ${ }^{1}$ & 1.00 & 1.00 & 1.00 \\
L-lysine·HCl & 0.35 & 0.77 & 0.76 \\
L-threonine & 0.09 & 0.30 & 0.29 \\
L-tryptophan & 0.04 & 0.11 & 0.11 \\
DL-methionine & 0.09 & 0.23 & 0.23 \\
L-isoleucine & & & 0.19 \\
L-valine & & & 0.27 \\
L-leucine & & & 0.07 \\
Total & 100 & 100 & 100 \\
\hline CON, the & &
\end{tabular}

$\mathrm{CON}$, the corn-soybean based diet; PR, the protein restricted diet; BCAA, the BCAA supplementation in PR diet; $\mathrm{CP}$, crude protein.

${ }^{1}$ Provided per kilogram of complete diet: 8,500 IU of vitamin A; $1,100 \mathrm{IU}$ of vitamin $\mathrm{D}_{3} ; 11.0 \mathrm{IU}$ of vitamin $\mathrm{E} ; 1.1 \mathrm{mg}$ of vitamin $\mathrm{K} ; 37.0 \mathrm{mg}$ of niacin; $800 \mathrm{mg}$ of choline chloride; $0.25 \mathrm{mg}$ of biotin; $0.12 \mathrm{mg}$ of vitamin $\mathrm{B}_{12} ; 0.75 \mathrm{mg}$ of folic acid; $45 \mathrm{mg}$ of $\mathrm{Mn} ; 105 \mathrm{mg}$ of $\mathrm{Zn} ; 100 \mathrm{mg}$ of $\mathrm{Fe} ; 20 \mathrm{mg}$ of $\mathrm{Cu} ; 0.30 \mathrm{mg}$ of Se; $0.10 \mathrm{mg}$ of I. 
Table 2. Analyzed chemical composition and amino acid content of experimental diets ${ }^{1}$

\begin{tabular}{|c|c|c|c|}
\hline Content & $\mathrm{CON}^{2}$ & PR & BCAA \\
\hline Crude protein $(\%)$ & 20.90 & 17.06 & 17.85 \\
\hline Dry matter $(\%)$ & 89.54 & 89.14 & 89.08 \\
\hline Moisture (\%) & 10.46 & 10.86 & 10.92 \\
\hline Ash (\%) & 6.38 & 5.47 & 5.66 \\
\hline Calcium (\%) & 0.88 & 0.85 & 0.85 \\
\hline Total phosphorus (\%) & 0.65 & 0.61 & 0.60 \\
\hline Metabolic energy (ME), $\mathrm{Kcal} / \mathrm{kg}^{2}$ & 3,280 & 3,280 & 3,280 \\
\hline \multicolumn{4}{|l|}{ Essential amino acid (\%) } \\
\hline Lysine & 1.45 & 1.45 & 1.50 \\
\hline Threonine & 0.94 & 0.90 & 0.89 \\
\hline Tryptophan & 0.27 & 0.28 & 0.29 \\
\hline Methionine & 0.62 & 0.53 & 0.55 \\
\hline Valine & 0.97 & 0.74 & 1.11 \\
\hline Isoleucine & 0.84 & 0.60 & 0.80 \\
\hline Leucine & 1.61 & 1.26 & 1.38 \\
\hline Phenylalanine & 0.95 & 0.69 & 0.72 \\
\hline Histidine & 0.59 & 0.45 & 0.45 \\
\hline Arginine & 1.24 & 0.83 & 0.87 \\
\hline \multicolumn{4}{|l|}{ Non-essential amino acid (\%) } \\
\hline Cystine & 0.47 & 0.37 & 0.36 \\
\hline Tyrosine & 0.48 & 0.34 & 0.37 \\
\hline Glycine & 0.85 & 0.64 & 0.65 \\
\hline Proline & 1.05 & 0.84 & 0.85 \\
\hline Methionine + cystine & 1.09 & 0.77 & 0.91 \\
\hline Alanine & 1.05 & 0.86 & 0.86 \\
\hline Serine & 0.90 & 0.64 & 0.65 \\
\hline Glutamate & 3.53 & 2.56 & 2.62 \\
\hline Aspartate & 1.99 & 1.35 & 1.41 \\
\hline
\end{tabular}

CON, the corn-soybean based diet; PR, the protein restricted diet; BCAA, the BCAA supplementation in PR diet.

${ }^{1}$ Values are adjusted to a dry matter content of $87.5 \%$.

${ }^{2}$ The metabolic energy of diets is calculated.

diets were presented in Table 1 and 2. Experimental diets were analyzed in triplicate for dry matter (method 930.15; AOAC, 2007), CP (method 990. 03; AOAC, 2007), ash (method 942. 05; AOAC, 2007), calcium, and phosphorus (method 985.01; AOAC, 2007). Amino acid composition of feed samples was determined by high-performance liquid chromatography (HPLC) after acid hydrolysis. The methionine and cystine were determined following oxidation with performic acid (Moore, 1963).

\section{Sample preparation}

At the 14th day of the trial (early morning at 15th, before pigs were fed), blood was collected from one pig (its $\mathrm{BW}$ close to the mean of BW in each pen) from each pen (six pigs per treatment [half barrow and half gilt]) via the anterior vena cava puncture using ethylene diamine tetraacetie acid-containing tubes for plasma AA analysis. And then the pig which blood was collected underwent electrical shock euthanasia. Two segments of 5 to $8 \mathrm{~cm}$ section of the middle of the duodenum, the jejunum and the ileum were first rinsed with ice-cold normal saline solution $(0.9 \% \mathrm{w} / \mathrm{v})$. One was placed into $4 \%$ paraformaldehyde solution and the other was stored at $-80^{\circ} \mathrm{C}$ until assay.

\section{Plasma free amino acids}

After collection, the blood samples were centrifuged at 3,000 rotations per minute at $4^{\circ} \mathrm{C}$ for $15 \mathrm{~min}$ and the plasma samples were allocated and stored at $-80^{\circ} \mathrm{C}$ until assay. Plasma FAA were determined by HPLC with precolumn 6aminoquinolyl-N-hydroxysuccinimidyl carbamate derivatization. Plasma was neutralized with 10\% 2-hydroxybenzoic-5sulfonic acid, blending. And the solution was centrifuged at 50,000 rotations per minute at $4^{\circ} \mathrm{C}$ for $15 \mathrm{~min}$ and the supernatant fluid was used to analyze the FAA (Sykam S433 AA analyzer, Munich, Germany).

\section{Intestinal histology and the number of lymph cells}

The preserved segments were treated using standard paraffin-embedding techniques. The intestinal samples were gradually dehydrated, sectioned at $5 \mu \mathrm{m}$ and stained with haematoxylin and eosin. The intestinal morphology was tested according to Pluske et al. (1996). The villous height and crypt depth were taken based on 15 apparently intact villi from each section on the stained sections $(10 \times$ objective $)$ and the results were shown as mean villous height or crypt depth in $\mu \mathrm{m}$. Villous height was measured from the cypth-villous junction to the tip. Crypt depth was measured from the crypt-villous junction to the base. The number of goblet cells and intra-epithelial lymphocytes (IELs) among 100 enterocytes in 15 different intestinal villi of each tissue was counted on the stained sections (40×objective) for the statistical analysis of the data. The targets were measured using the light microscope (BX51; Olympus, Osaka, Japan) fitted with an image analyser (Image-Pro Plus; Media Cybernetics, Sliver Spring, MD, USA).

\section{Intestinal immunoglobulins}

The levels of sIgA (lower limit $0.15 \mu \mathrm{g} / \mathrm{mL}$ ), immunoglobulin A (IgA) (lower limit $0.146 \mu \mathrm{g} / \mathrm{mL}$ ), immunoglobulin $\mathrm{M}$ (IgM) (lower limit $0.04 \mu \mathrm{g} / \mathrm{mL}$ ) and immunoglobulin $\mathrm{G}$ ( $\mathrm{IgG}$ ) (lower limit $0.58 \mu \mathrm{g} / \mathrm{mL}$ ) from small intestine were determined as described previously (Zhang et al., 2013) using commercially available sandwich enzyme-linked immunosorbent assay kit (Cusabio). Jejunum and ileum tissue were isolated and mixed in $5 \mathrm{~mL}$ phosphate buffer solution (PBS, $0.01 \mathrm{M}$ ) supplemented with $1 \%$ protease inhibitor (Sigma-Aldrich Company, Louis, MO, USA). Homogenized samples were ultracentrifuged for 10 min at 5,000 rotations per minute and the immunoglobulin 
Table 3. Growth performance of weaned piglets in different diets

\begin{tabular}{lccccc}
\hline Item & CON & PR & BACC & SEM $^{2}$ & p value \\
\hline Initial weight $(\mathrm{kg})$ & 8.03 & 7.92 & 7.92 & 0.26 & 0.99 \\
Final weight $(\mathrm{kg})$ & $12.27^{\mathrm{a}}$ & $10.36^{\mathrm{b}}$ & $11.92^{\mathrm{a}}$ & 0.41 & $<0.01$ \\
ADG $(\mathrm{g} / \mathrm{d})$ & $303^{\mathrm{a}}$ & $174^{\mathrm{b}}$ & $286^{\mathrm{a}}$ & 16.84 & $<0.01$ \\
ADFI $(\mathrm{g} / \mathrm{d})$ & $366^{\mathrm{a}}$ & $300^{\mathrm{b}}$ & $383^{\mathrm{a}}$ & 14.55 & $<0.01$ \\
Feed:gian $(\mathrm{g} / \mathrm{g})$ & $1.21^{\mathrm{a}}$ & $1.73^{\mathrm{b}}$ & $1.34^{\mathrm{a}}$ & 0.07 & $<0.01$ \\
\hline
\end{tabular}

CON, the corn-soybean based diet; PR, the protein restricted diet; BCAA, the BCAA supplementation in PR diet; SEM, standard error of the mean; ADG, average daily gain; ADFI, average daily feed intake.

Values are presented as mea, $n=6$ pen per treatment. Different superscripts indicate significant difference $(\mathrm{p}<0.05)$.

and total protein in the supernatant were measured by using kits. Add $50 \mu \mathrm{L}$ standard or sample and $50 \mu \mathrm{L}$ horseradish peroxidase-conjugate to a blank well. Mix well with the pipette or shake the plate. Then incubate for $40 \mathrm{~min}$ at $37^{\circ} \mathrm{C}$. Aspirate each well and wash. Then all $90 \mu \mathrm{L} 3,3^{\prime}, 5,5^{\prime}-$ tetramethyl-benzidine substrate to each well and incubate for $20 \mathrm{~min}$ at $37^{\circ} \mathrm{C}$. Add stop solution and read the plate using a microplate reader (Bio-Rad, Hercules, CA, USA). The total protein concentration of each sample solution was determined by BCA protein assay (Pierce, Rockford, IL, USA) kit (test range 20 to $2,000 \mu \mathrm{g} / \mathrm{mL}$ ) according to the supplier's instructions. And the immunoglobulin data was collected as the immunoglobulin level to total protein concentration ratio of each pig sample.

\section{Statistical analysis}

The pen was used as the experimental unit for the analysis of growth performance, whereas individual piglet was used as experimental unit for analysis of other indexes. The data of growth performance and plasma AA concentration were analyzed by using general linear model procedure of SAS (Version 8.1; SAS Institute, Gary, NC, USA). The repeated measurements data on intestinal morphology, cell numbers, immunoglobulins across different locations of the small intestine were analyzed with repeat measure analysis. Differences among treatments were analyzed by Duncan's multiple rang test. Probability values less than 0.05 were considered significance. Probability values between 0.1 to 0.05 were considered tendency.

\section{RESULTS}

\section{Growth performance and concentrations of plasma free amino acid}

In results, final $\mathrm{BW}, \mathrm{ADG}, \mathrm{ADFI}$, and $\mathrm{G}: \mathrm{F}$ were greater $(p<0.05)$ in pigs fed the CON and BCAA diets than pigs fed the PR diet (Table 3). In Table 4, the plasma urea concentration of pigs was declined $(p<0.05)$ in the BCAA group than $\mathrm{CON}$ and $\mathrm{PR}$ groups (the plasma urea

Table 4. Amino acid concentration in plasma of piglets with different diets $(\mathrm{nmol} / \mathrm{mL})$

\begin{tabular}{|c|c|c|c|c|c|}
\hline Amino acids & $\mathrm{CON}$ & PR & BACC & SEM & $\mathrm{p}$ value \\
\hline Lysine & 651.17 & 715.60 & 774.47 & 57.28 & 0.78 \\
\hline Methionine & $89.04^{\mathrm{a}}$ & $151.21^{\mathrm{b}}$ & $160.11^{\mathrm{b}}$ & 13.04 & 0.04 \\
\hline Cysteine & 9.24 & 4.95 & 7.70 & 0.83 & 0.56 \\
\hline Threonine & $379.06^{\mathrm{a}}$ & $517.30^{\mathrm{b}}$ & $534.25^{\mathrm{b}}$ & 36.84 & 0.03 \\
\hline Tryptophan & 81.06 & 98.02 & 85.17 & 5.40 & 0.43 \\
\hline Isoleucine & $173.81^{\mathrm{a}}$ & $62.04^{\mathrm{b}}$ & $194.10^{\mathrm{a}}$ & 16.40 & $<0.01$ \\
\hline Leucine & $268.42^{\mathrm{a}}$ & $153.45^{\mathrm{b}}$ & $203.52^{\mathrm{ab}}$ & 15.17 & $<0.01$ \\
\hline Valine & $163.95^{\mathrm{b}}$ & $114.96^{\mathrm{c}}$ & $367.09^{\mathrm{a}}$ & 40.86 & $<0.01$ \\
\hline Proline & 357.57 & 290.82 & 277.09 & 27.95 & 0.48 \\
\hline Arginine & $352.55^{\mathrm{a}}$ & $119.34^{\mathrm{b}}$ & $124.40^{\mathrm{b}}$ & 32.79 & $<0.01$ \\
\hline Glycine & $1,396.84$ & $1,492.36$ & $1,216.40$ & 99.19 & 0.64 \\
\hline Aspartate & 228.52 & 185.15 & 159.42 & 25.06 & 0.39 \\
\hline Serine & 303.38 & 288.65 & 250.06 & 28.12 & 0.75 \\
\hline Phenylalanine & $114.84^{\mathrm{a}}$ & $66.54^{\mathrm{b}}$ & $68.72^{\mathrm{b}}$ & 6.99 & $<0.01$ \\
\hline Histidine & $93.70^{\mathrm{a}}$ & $40.45^{\mathrm{b}}$ & $24.45^{\mathrm{b}}$ & 7.53 & $<0.01$ \\
\hline Alanine & $1,038.81$ & $1,327.71$ & $1,239.62$ & 121.03 & 0.85 \\
\hline Glutamine & 768.73 & 999.69 & $1,096.05$ & 110.07 & 0.15 \\
\hline Urea & $348.14^{\mathrm{a}}$ & $176.69^{\mathrm{b}}$ & $98.22^{\mathrm{c}}$ & 30.15 & $<0.01$ \\
\hline
\end{tabular}

CON, the corn-soybean based diet; PR, the protein restricted diet; BCAA, the BCAA supplementation in PR diet; SEM, standard error of the mean. Values are presented as mean, $n=6$ pigs per treatment. Different superscripts indicate significant difference $(p<0.05)$. 
concentration of BCAA group was lowered $71.8 \%$ than that of the CON group, and lowered $44.4 \%$ than that of the PR group). The pigs fed the PR and BCAA diets had a higher plasma concentration of methionine and threonine than pigs fed the CON diet. Following the reduced protein content in diet, the level of some essential and functional AA (arginine, phenylalanine, histidine, isoleucine, valine, and leucine) in plasma of PR group was lower than that of the CON group $(p<0.05)$. Compared to the PR group, the supplementation of BCAA increased plasma concentration of isoleucine, leucine and valine in the BCAA group $(p<0.05)$. The level of valine in pigs fed BCAA diet was higher than pig fed the CON and PR diets $(\mathrm{p}<0.05)$.

\section{Intestinal morphology}

No effect of the CON, PR, and BCAA diets on villous height, crypt depth, and the ratio of villous height and crypt depth was observed in either jejunum or ileum of piglets $(p>0.05)$ (Figure 1). However, compared with CON treatment, a lower on the villous height $(p=0.003)$ and the villous height:crypt depth ratio $(p=0.009)$ was observed in the duodenum in PR treatment. Pigs offered the BCAA diet had an increased villous height in the duodenum compared with pigs offered the PR diets $(\mathrm{p}<0.05)$.

\section{Intestinal immunoglobulin and intra-epithelial lymphocytes}

Pigs offered different diets had the same epithelial goblet cell number in whole intestine. The IELs number of PR group was observed more than that of CON and BCAA groups in the duodenum $(\mathrm{p}<0.01)$, the jejunum $(\mathrm{p}=0.007)$ or the ileum $(\mathrm{p}=0.07)$ (Figure 2). Compared with the CON and BCAA groups, a decline of $\operatorname{sigA}(\mathrm{p}=0.03), \operatorname{IgA}(\mathrm{p}=$ $0.04)$ and $\operatorname{IgM}(p=0.08)$ was noticed in the jejunum of the PR group (Table 5). The expression of $\operatorname{IgA}(\mathrm{p}=0.01)$ and $\operatorname{IgG}(p=0.08)$ in ileum of the PR group was also lower than
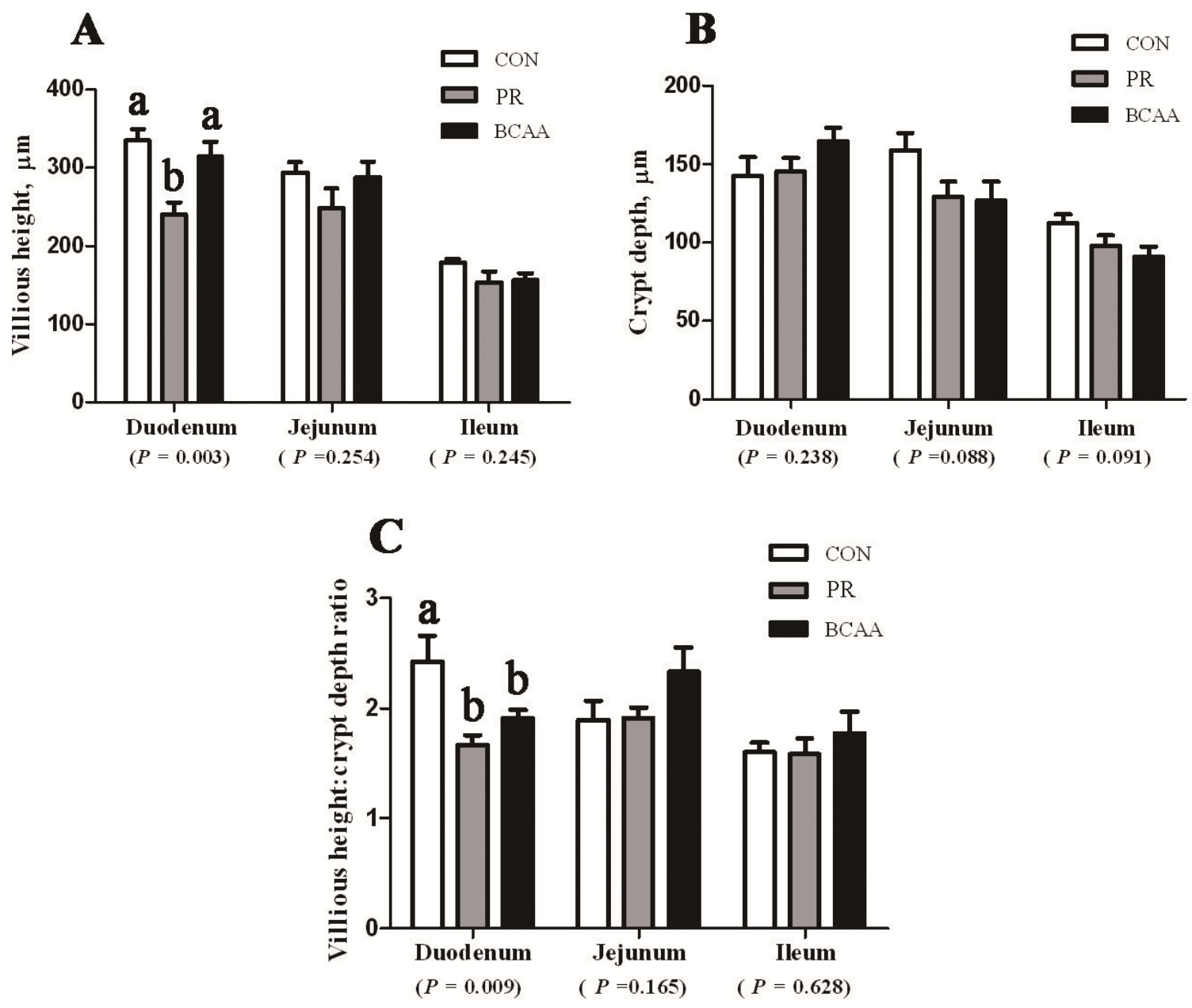

Figure 1. The villous height (A), crypt depth (B) and villous height:crypt depth ratio (C) in small intestine of pigs offered three diets for 2 wk. From left to right, bars represent area of the intestine from duodenum to ileum. White bars, gray bars or black bars represent CON, $\mathrm{PR}$, or BCAA treatment, respectively. Values are presented as mean \pm SEM, $\mathrm{n}=6$ pigs per treatment. The "a" and " $\mathrm{b}$ " indicates mean values with unlike letters were significantly different $(\mathrm{p}<0.05)$. CON, the corn-soybean based diet; PR, the protein restricted diet; BCAA, the BCAA supplementation in PR diet; SEM, standard error of the mean. 

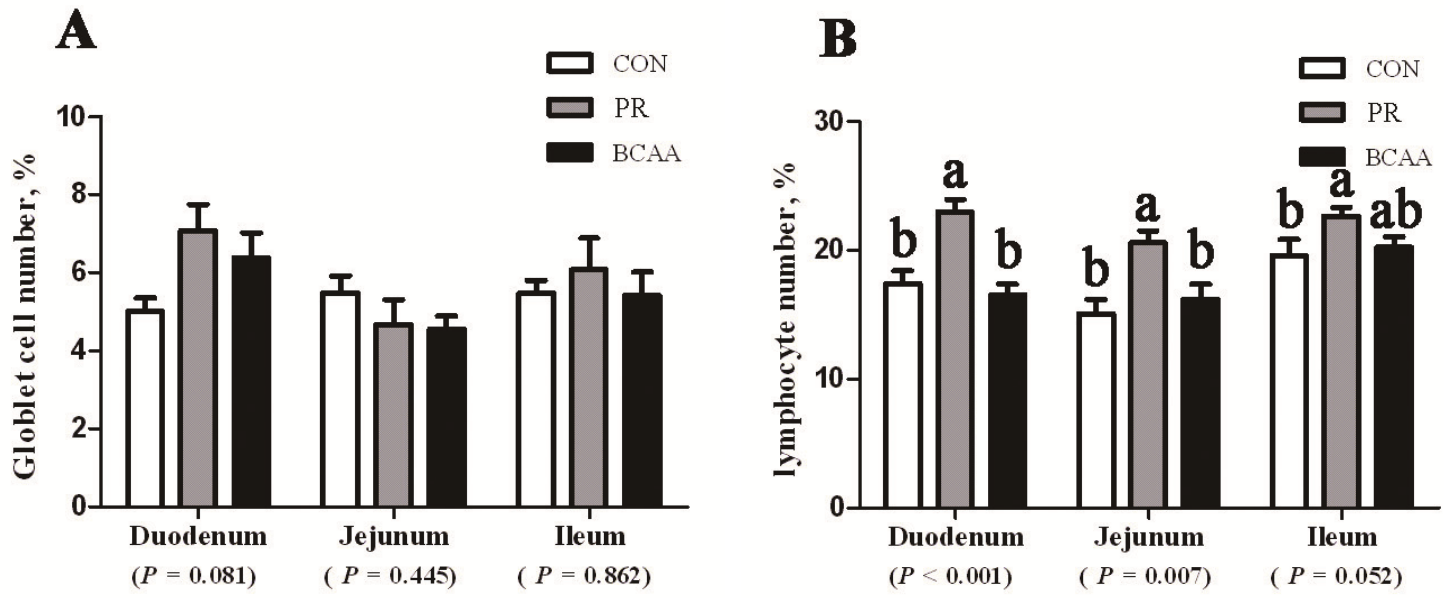

Figure 2. The epithelial goblet cell number (A) and intra-epithelial lymphocyte (IELs) number (B) in small intestine of pigs offered three diets for $2 \mathrm{wk}$. From left to right, bars represent area of the intestine from duodenum to ileum. White bars, gray bars or black bars represent CON, PR, or BCAA treatment, respectively. Values are presented as mean \pm SEM, $n=6$ pigs per treatment. The "a" and " $b$ " indicates mean values with unlike letters were significantly different $(\mathrm{p}<0.05)$. CON, the corn-soybean based diet; PR, the protein restricted diet; BCAA, the BCAA supplementation in PR diet; SEM, standard error of the mean.

that of CON and BCAA groups.

\section{DISCUSSION}

Weaning in pigs, associated with social, environmental and dietary stress, deteriorated the intestinal barrier and absorption function (McCracken et al., 1995). During the first two weeks of repairing period after weaning, the most important thing is to decrease the stress and the irritation of antigens from feed and provide nutrients which could be rapidly absorbed and utilized (Wijtten et al., 2011). The growth performance of weaned piglet directly reflects the health and recovery of intestine from weaning stress (Zijlstra et al., 1994). In the present study, the PR treatment had the lower ADG and ADFI indicated that supplementing four essential AA (lysing, methionine, threonine, and tryptophan) in low protein diet was insufficient to maintain growth of weaned pig. The reduced performance is mainly due to the deficient of protein and possibly indicates the dispensable AA are also very important for production. Nyachoti et al. (2006) got a similar result that compared with $23 \% \mathrm{CP}, 21 \% \mathrm{CP}$, or $19 \% \mathrm{CP}$ diet, weaned pigs offered the low CP diet (containing 17\% CP and crystalline lysine, methionine, threonine, and tryptophan) had a significantly lower performance. We found that the supplementation of BCAA in PR diet improved all growth indexes. On the contrary, Heo et al. (2008) reported that the growth performance of pigs was not affected by dietary CP level when crystalline AA were applied. These discrepancies are due to differences in pig breed and weaning age, the duration of experiment, the ingredient of diet and the degree of dietary protein reduction.

As a physical barrier to absorb nutrients and against pathogens, the small intestine exerts its function based on the villous and crypt hyperplasia to expand the secondary mucosal surface area in preparation for the nutrient load

Table 5. The concentration of immunoglobulin in the small intestine of piglets with different diets

\begin{tabular}{|c|c|c|c|c|c|}
\hline Content & $\mathrm{CON}$ & PR & BACC & SEM & $\mathrm{p}$ value \\
\hline \multicolumn{6}{|c|}{ Concentration/jejunal tissue (mg/g) } \\
\hline $\operatorname{sIg} \mathrm{A}$ & $5.83^{\mathrm{a}}$ & $4.86^{\mathrm{c}}$ & $5.06^{\mathrm{b}}$ & 0.19 & 0.03 \\
\hline IgA & $15.52^{\mathrm{a}}$ & $13.10^{\mathrm{c}}$ & $14.23^{\mathrm{b}}$ & 0.46 & 0.04 \\
\hline $\operatorname{IgG}$ & 65.14 & 56.64 & 63.41 & 2.42 & 0.22 \\
\hline $\operatorname{IgM}$ & $13.05^{\mathrm{a}}$ & $10.55^{\mathrm{b}}$ & $11.91^{\mathrm{ab}}$ & 0.47 & 0.08 \\
\hline \multicolumn{6}{|c|}{ Concentration /ileal tissue $(\mathrm{mg} / \mathrm{g})$} \\
\hline $\operatorname{sIg} \mathrm{A}$ & 5.86 & 4.40 & 5.55 & 0.35 & 0.15 \\
\hline $\operatorname{IgA}$ & $16.91^{\mathrm{a}}$ & $11.86^{\mathrm{b}}$ & $15.58^{\mathrm{a}}$ & 0.96 & 0.01 \\
\hline IgG & $74.05^{\mathrm{a}}$ & $51.26^{\mathrm{b}}$ & $68.94^{\mathrm{ab}}$ & 5.33 & 0.08 \\
\hline $\operatorname{IgM}$ & 15.56 & 12.70 & 14.48 & 0.90 & 0.31 \\
\hline
\end{tabular}

CON, the corn-soybean based diet; PR, the protein restricted diet; BCAA, the BCAA supplementation in PR diet; SEM, standard error of the mean; sIgA, secretory immunoglobulin A; IgA, immunoglobulin A; IgG, immunoglobulin G; IgM, immunoglobulin M.

Values are presented as mean, $n=6$ pigs per treatment. Different superscripts indicate significant difference $(p<0.05)$. 
during weaning (Cummins and Thompson, 2002). Villous height is halved 5 days after weaning and crypt depth is further increased by weaning while the changes in gut morphology are primarily related to inadequate nutrients caused by the low feed intake and intestinal inflammation during weaning (Miller et al., 1986; Nabuurs et al., 1993; Pluske et al., 1996). The reduction in dietary protein levels tended to decrease intestinal villous height and the ratio of villous height:crypt depth in weaning piglets (Guay et al., 2006), probably because of the severe lacking of nutrients, especially AA. Plasma concentration of AA is a dynamic process, which can be due to both of lower uptake of AA from $\mathrm{PR}$ diet and increased peripheral absorption of circulating AA. The methionine and threonine in plasma of pigs fed the PR and BCAA diet were higher than that of the CON group indicated that crystalline AA are absorbed easily and fast by intestine. Consistently, in this study, the plasma concentrations of many un-supplemented AA in the PR group, such as isoleucine, leucine, valine, arginine, phenylalanine, and histidine, were significantly lower than that in the control diet. The proper supplementation of BCAA possibly improved the intestinal morphology through the rapid absorption and utilization of crystalline AA (Stoll et al., 1998). In contrast with the control group, the BCAA group had a higher concentration of supplemented AA in plasma although plasma concentration of arginine, histidine, and phenylalanine in BCAA group was lower than the control group. BCAA supplementation might have beneficial for the utilization of dietary nitrogen and reduced nitrogen excretion (NRC, 2012). Plasma urea nitrogen is reduced linearly with the decrease in the protein content, while there was a positive correlation between the nitrogen excretion and plasma urea concentration (Figueroa et al., 2002; Kerr, 2003; Nyachoti et al., 2006; Lordelo et al., 2008). Our study found that the plasma urea concentration of pigs fed the PR diet was decreased by $49.2 \%$ than that of pigs fed the control diet. Supplementation of BCAA in the protein restricted diet decreased the plasma urea concentration of pigs by $71.8 \%$ or $44.4 \%$ compared with the CON group or the PR group, respectively. The results indicated that reducing dietary protein levels possibly decline nitrogen excretion in weaned pig, meanwhile BCAA supplementation can make it further declining through balancing the limitation of dietary AA.

Presently it has already become a consensus of modern nutrition and immunology that the layer of epithelial cells lining the small intestine not only digests and absorbs nutrients but also serves as a barrier against noxious antigens and pathogens in intestinal lumen (Oswald, 2006). The lymphocytes are recruited to the intestinal mucous, which induces an augment in IEL number during the postweaning period and illustrates a post-weaning activation of the immune system (Nofrarías et al., 2006). Meanwhile, immunoglobulin, inflammatory cytokines (Pié et al., 2004), antimicrobial peptides and other immune-related proteins (Pomorska-Mól and Markowska-Daniel, 2011) are produced and secreted into gut lumen to protect and repair the intestinal mucosa of weaned piglets. Early intestinal immune response and gut disorders in post-weaning piglets can be influenced by dietary nutrients (Wu, 1998). In the current study, reducing dietary protein level significantly increased the number of IELs in the whole gut and declined the concentration of $\operatorname{sg} \mathrm{A}, \operatorname{IgA}$, and $\operatorname{IgM}$ in the jejunum or IgA and IgG the ileum of pigs fed the PR diet. A large number of lymphocytes in the villous epithelium, IELs, are a striking feature of the small intestinal mucosa. These cells consist of several ontogenically and phenotypically distinct populations of T cells (Guy-Grand, 1998) and they are one of the immune cells in intestinal epithelium that are involved in the development of tolerance and adaptive response to lumenal antigens while IELs perform surveillance of the epithelium (Lundqvist et al., 1995). In some conditions of excessive antigenic stimulation of the IEL might be responsible for the characteristic small bowel lesions of villous atrophy and crypt hyperplasia (Guy-Grand et al., 1998). Immunoglobulin especially sIgA translocate across the IEC layer toward the lumen and are deposited in the intestinal mucus layer to strengthen the first layer of defense against bacteria (Wells et al., 2010). The presence of high concentrations of $\operatorname{sgA}$ in the mucus layer restricts commensal microbes from gaining entry to the lamina propria (Kinnebrew, 2012). We have proved that lacking of AA is adverse to the immune response including the raising of IELs number and the reducing of immunoglobulin. In current study, lacking of AA impaired the intestinal immune response including the raising of IELs number and the reducing of immunoglobulin. In post-weaning pig intestine, the nutritional requirement (especially AA and glucose) of intestinal epithelium is increased by elevated rates of substrate metabolism in IELs and synthesis of immune related protein (Dugan et al., 1994; Lallès et al., 2007). Supplementation of AA and easily absorbed protein, e.g. arginine (Zhu et al., 2013), glutamine (Doppenberg and van der Aar, 2010), BCAA (current study) and spray-dried plasma proteins (Doppenberg and van der Aar, 2010), prevented the elevation of IELs numbers and the declining of immunoglobulin. The results, that the BCAA supplementation diet decreased IEL number and significantly increased the immunoglobulins expression in the intestine of pigs, attested above point.

Epithelium absorbs a mass of AA from intestinal lumen to synthesize proteins related to immune and nutritional transport. Moreover AA can also provide energy to epithelium cells ( $\mathrm{Wu}, 1998 ; \mathrm{Wu}, 2009)$. The weaning stress and immune response intensifies the requirement of AA in gut of weaned pig ( $\mathrm{Li}$ et al., 2007). Apart from reducing 
nitrogen excretion, supplementation of BCAA in protein restricted diet improves the gut health. The reasons might be that: firstly, stimulus from dietary antigens was lower in small intestine for declining of soybean anti-nutritional protein; secondly, BCAA have higher efficiency to absorption and utilization than whole compound protein; lastly, BCAA ameliorate mucus immune function and protect intestinal villi from negative effect of restricted protein diet. However, more research is needed about the mechanisms of BCAA on intestinal immune system. For example, whether (IELs) or goblet cells or other epithelial cells can utilize BCAA to apply energy and synthesize immune protein and cytokines. How could BCAA improve the expression of $\operatorname{sIgA}$ and intestinal host defense proteins?

In conclusion, the supplementation of BCAA was necessary in protein restricted diet to maintain growth performance and the gut health through improving immunity and synthesis of immunoglobulins in intestine. Our finding has an implication that BCAA may be used to reduce ameliorate growth stasis in weaned piglets.

\section{ACKNOWLEDGMENTS}

We appreciate Global Bio-Chem Technology Inc. for the generous gift of the feed grade L-lysine sulfate that had been used in this study.

Supported by the National Basic Research Program (2012CB124704).

\section{REFERENCES}

AOAC. 2007. Official Methods of Analysis. 18th ed. AOAC international, Gaithersburg, MD, USA.

Calder, P. C. and P. Yaqoob. 1999. Glutamine and the immune system. Amino Acids 17:227-241.

Carr, L. E., A. Kelman, S. G. Wu, R. Gopaul, E. Senkevitch, A. Aghvanyan, A. M. Turay, and K. A. Frauwirth. 2010. Glutamine uptake and metabolism are coordinately regulated by ERK/MAPK during T lymphocyte activation. J. Immunol. 185:1037-1044.

Con, J., B. Joseph, N. Kulvatunyou, A. Tang, T. O'Keeffe, J. L. Wynne, R. S. Friese, P. Rhee, and R. Latifi. 2011. Evidencebased immune-modulating nutritional therapy in critically ill and injured patients. Eur. Surg. 43:13-18.

Cummins, A. G. and F. M. Thompson. 2002. Effect of breast milk and weaning on epithelial growth of the small intestine in human. Gut 51:748-754.

Doppenberg, J. and P. J. van der Aar. 2010. Dynamics in Animal Nutrition. Wageingen Accademic Publishers, Wageingen, The Netherlands. Page 31-36.

Dugan, M. E. R., D. A. Knabe, and G. Wu. 1994. Glutamine and glucose metabolism in intraepithelial lymphocytes from preand post-weaning pigs. Comp. Biochem. Phys. B. Comp. Biochem. 109:675-681.

Evoy, D., M. D. Lieberman, T. J. Fahey, and J. M. Daly. 1998.
Immuninutrition: The role of arginine. Nutrition 14:611-617.

Figueroa, J. L., A. J. Lewis, P. S. Miller, R. L. Fischer, R. S. Gómez, and R. M. Diedrichsen. 2002. Nitrogen metabolism and growth performance of gilts fed standard maize-soybean meal diets or low-crude protein, amino acid supplemented diets. J. Anim. Sci. 80:2911-2919.

Guay, F., S. M. Donovan, and N. L. Trottier. 2006. Biochemical and morphological developments are practically impaired in intestinal mucosa from growing pigs fed reduced-protein diets supplemented with crystalline amino acids. J. Anim. Sci. 84:1749-1760.

Guy-Grand, D, J. P. DiSanto, P. Henchoz, M. Malassis-Séris, and P. Vassalli. 1998. Small bowel enteropathy: role of interepithelial lymphocytes and of cytokines (IL-12, INF- $\gamma$, TNF) in the induction of epithelial cell death and renewal. Eur. J. Immunol. 28:730-744.

Heo, J. M., J. C. Kim, C. F. Hansen, B. P. Mullan, D. J. Hanpson, and J. R. Pluske. 2008. Effects of feeding low protein diets to piglets on plasma urea nitrogen, faecal ammonia nitrogen, the incidence of diarrhoea and performance after weaning. Arch. Anim. Nutr. 62:343-358.

Htoo, J. K., B. A. Araiza, W. C. Sauer, M. Rademacher, Y. Zhang, M. Cervantes, and R. T. Aijlstra. 2007. Effect of dietary protein content on ileal amino acid digestibility, growth performance, and formation of microbial metabolites in ileal and cecal digest of early-weaned pigs. J. Anim. Sci. 85:3303-3312.

Kerr, B. J. 2003. Dietary manipulation to reduce environmental impact. Page139-158 in 9th International Symposium on Digestive Physiology in Pigs, May 14-17, 2003; Banff, Alberta, Canada.

Kinnebrew, M. A. and E. G. Pamer. 2012. Innate immune signaling in defense against intestinal microbes. Immunol. Rev. 245:113131

Lallès, J. P., P. Bosi, H. Smidt, and C. R. Stokes. 2007. Nutritional management of gut health in pigs around weaning. Proc. Nutr. Soc. 66:260-268.

Li, P., Y. Yin, D. Li, S. W. Kim, and G. Wu. 2007. Amino acids and immune function. Br. J. Nutr. 98:237-252.

Lordelo, M. M., A. M. Gaspar, L. Le Bellego, and J. P. B. Freire. 2008. Isoleucine and valine supplementation of a low-protein corn-wheat-soybean meal-based diet for piglets: growth performance and nitrogen balance. J. Anim. Sci. 86:2936-2941.

Lundqvist, C., V. Baranov, S. Hammarstrōm, L. Athlin, and M. L. Hammarstrōm. 1995. Intra-epithelial lymphocytes. Evidence for regional specialization and extrathymic $\mathrm{T}$ cell maturation in the human gut epithelium. Int. Immunol. 7:1473-1487.

Mao, X., X. Zeng, S. Qiao, G. Wu, and D. Li. 2011. Specific roles of threonine in intestinal mucosal integrity and barrier function. Front Biosci. E3:1192-1200.

McCracken, B. A., H. R. Gaskins, P. J. Ruwe-Kaiser, K. C. Klasing, and D. E. Jewell. 1995. Diet-dependent and dietindependent metabolic responses underlie growth stasis of pigs at weaning. J. Nutr. 125:2838-2845.

McGuckin, A. M., R. Eri, L. A. Simms, T. H. J. Florin, and G. Radford-Smith. 2009. Intestinal barrier dysfunction in inflammatory bowel diseases. Inflamm. Bowel Dis. 15:100113.

Miller, B. G., P. S. Jamies, M. W. Smith, and F. J. Bourne. 1986. 
Effect of weaning on the capacity of pig intestinal villi to digest and absorb nutrients. J. Agric. Sci. Camb. 107:579-589.

Moore, S. 1963. On the determination of cystine as cysteic acid. J. Biol. Chem. 238:235-237.

Nabuurs, M. J., A. Hoogendoorn, E. J. V. Molen, and A. L. Van Osta. 1993. Villous height and crypt depth in weaned and unweaned pigs, reared under various circumstances in the Netherlands. Res. Vet. Sci. 55:78-84.

NRC. 1998. Nutrient Requirements of Swine, 10th Edition. National Academy Press, Washington DC, USA.

NRC. 2012. Nutrient Requirements of Swine, 11th Edition. National Academy Press, Washington DC, USA.

Nofrarías, M., E. G. Manzanilla, J. Pujols, X. Gibert, N. Majó, J. Segalés and J. Gasa. 2006. Effects of spray- dried porcine plasma and plant exreacts on intestinal morphology and on leukocyte cell subsets of weaned pigs. J. Anim. Sci. 84:27352742.

Nyachoti, C. M., F. O. Omoghenigun, M. Rademacher, and G. Blank. 2006. Performance responses and indicators of gastrointestinal health in early-weaned pigs fed low-protein amino acids-supplemented diets. J. Anim. Sci. 84:125-134.

Oswald, I. P. 2006. Role of intestinal epithelial cells in the innate immune defence of the pig intestine. Vet. Res. 37:359-368.

Wijtten, J. A. P., J. van der Meulen, and M. W. A. Verstegen. 2011. Intestinal barrier function and absorption in pigs after weaning: A review. Br. J. Nutr. 105:967-981.

Pié, S., J. P. Lallè, F. Blazy, J. Laffitte, B. Sève, and I. P. Oswald. 2004. Weaning is associated with an upregulation of expression of inflammatory cytokines in the intestine of piglets. J. Nutr. 124:641-647.

Pluske, J. R., M. J. Thompson, C. S. Atwood, P. H. Bird, I. H. Williams, and P. E. Hartmann. 1996. Maintenance of villous height and crypt depth, and enhancement of disaccharide digestion and monosaccharide absorption, in piglets fed on cows' whole milk after weaning. Br. J. Nutr. 76:409-422.

Pomorska-Mól, M. and I. Markowska-Daniel. 2011. Porcine cathelicidins and defensins. Med. Weter 67:20-24.

Powell, D. J., K. N. Pollizzi, E. B. Heikamp, and M. R. Horton. 2012. Regulation of immune responses by mTOR. Annu. Rev. Immunol. 30:39-68.

Rose, N., G. Larour, G. Le Digyerher, E. Everno, J. P. Jolly, P. Blanchard, A. Oger, M. Le Dimna, A. Jestin, and F. Madec. 2003. Risk factors for porcine post-weaning multisystemic wasting syndrome (PMWS) in 149 French farrow-to-finish herds. Prev. Vet. Med. 61:209-225.

Santaolalla, R., M. Fukata, and M. T. Abreu. 2011. Innate immunity in the small intestine. Curr. Opin. Gastroenterol. 27:125-131.
Simone, D. R., F. Vissicchio, C. Mingarelli, C. D. Nuccio, S. Visentin, M. A. Ajmone-Cat, and L. Minghetti. 2013. Branched-chain amino acids influence the immune properties of microglial cells and their responsiveness to proinflammatory signals. Biochim. Biophys. Acta Mol. Basis Dis. 1832:650-659.

Smith, F., J. E. Clark, B. L. Overman, C. C. Tozel, J. H. Huang, J. E. F Rivier, A. T. Blisklager, and A. J. Moeser. 2010. Early weaning stress impairs development of mucosal barrier function in the porcine intestine. Am. J. Physiol. Gastrointest. Liver Physiol. 298:352-363.

Stoll, B., J. Henry, P. J. Reeds, H. Yu, F. Jahoor, and D. G. Burrin. 1998. Catabolism dominates the first-pass intestinal metabolism of dietary essential amino acids in milk protein-fed piglets. J. Nutr. 128:606-614.

Tan, B., X. G. Li, X. Kong, R. Huang, Z. Ruan, K. Yao, Z. Deng, M. Xie, I. Shinzato, Y. Yin, and G. Wu. 2009. Dietary Larginine supplementation enhances the immune status in earlyweaned pglets. Amino Acids. 37:323-331.

Wang, J. J., L. Chen, P. Li, X. Li, H. Zhou, F. Wang, D. Li, Y. Yin, and G. Wu. 2008. Gene expression is altered in piglet small intestine by weaning and dietary glutamine supplementation. J. Nutr. 138:1025-1032.

Wells, J. M., L. M. P. Loonen, and J. M. Karczewski. 2010. The role of innate signalling in the homeostasis of tolerance and immunity in the intestine. Int. J. Med. Microbiol. 300:41-48.

Wu, G. 1998. Intestinal mucosal amino acid catabolism. J. Nutr. 128:1249-1252.

Wu, G. 2009. Amino acids: Metabolism, functions, and nutrition. Amino Acids 37:1-17.

Yoneda, J., A. Andou, and K. Takehana. 2009. Regulatory roles of amino acids in immune response. Curr. Rheumatol. Rev. 5:252-258.

Yue, L. Y. and S. Y. Qiao. 2007. Effects of low-protein diets supplemented with crystalline amino acids on performance and intestinal development in piglets over the first 2 weeks after weaning. Livest. Sci. 115:144-152.

Zhang, F., X. Zeng, F. Yang, Z. Huang, H. Liu, X. Ma, and S. Qiao. 2013. Dietary N-carbamylglutamate supplementation boosts intestinal mucosal immunity in Escherichia coli challenged piglets. Plos One. 8(6):e66280.

Zhu, H. L., Y. L. Liu, X. L. Xie, J. J. Huang, and Y. Q. Hou. 2013. Effect of L-arginine on intestinal mucosal immune barrier function in weaned pigs after Escherichia coli LPS challenge. Innate Immun. 19:242-252.

Zijlstra, R. T., J. Odle, W. F. Hall, B. W. Petschow, H. B. Gelbery, and R. E. Litov. 1994. Effect of orally administered epidermal growth factor on intestinal recovery of neonatal pigs infected with rotavirus. J. Pediatr. Gastroenterol. Nutr. 19:382-390. 